"Assessing the progress of exports diversification in Saudi Arabia: growth-share matrix approach"

\begin{tabular}{|c|c|}
\hline AUTHORS & Mohammad Imdadul Haque (D https://orcid.org/0000-0001-6323-032X \\
\hline ARTICLE INFO & $\begin{array}{l}\text { Mohammad Imdadul Haque (2020). Assessing the progress of exports } \\
\text { diversification in Saudi Arabia: growth-share matrix approach. Problems and } \\
\text { Perspectives in Management, 18(3), 118-128. doi:10.21511/ppm.18(3).2020.10 }\end{array}$ \\
\hline DOI & http://dx.doi.org/10.21511/ppm.18(3).2020.10 \\
\hline RELEASED ON & Tuesday, 25 August 2020 \\
\hline RECEIVED ON & Sunday, 19 April 2020 \\
\hline \multirow[t]{2}{*}{ ACCEPTED ON } & Wednesday, 12 August 2020 \\
\hline & \begin{tabular}{|l|}
$(c))$ EY \\
\end{tabular} \\
\hline LICENSE & $\begin{array}{l}\text { This work is licensed under a Creative Commons Attribution } 4.0 \text { International } \\
\text { License }\end{array}$ \\
\hline JOURNAL & "Problems and Perspectives in Management" \\
\hline ISSN PRINT & $1727-7051$ \\
\hline ISSN ONLINE & $1810-5467$ \\
\hline PUBLISHER & LLC “Consulting Publishing Company “Business Perspectives” \\
\hline FOUNDER & LLC "Consulting Publishing Company "Business Perspectives" \\
\hline
\end{tabular}

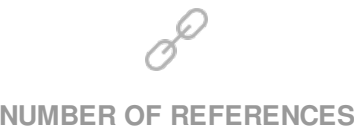

27

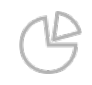

NUMBER OF FIGURES

3

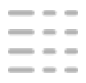

NUMBER OF TABLES

10

(C) The author(s) 2021. This publication is an open access article. 


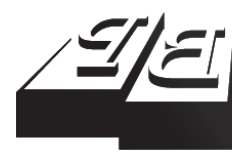

\section{BUSINESS PERSPECTIVES}

LLC "CPC "Business Perspectives" Hryhorii Skovoroda lane, 10, Sumy, 40022, Ukraine www.businessperspectives.org
Received on: $19^{\text {th }}$ of April, 2020 Accepted on: $12^{\text {th }}$ of August, 2020 Published on: $25^{\text {th }}$ of August, 2020

(c) Mohammad Imdadul Haque, 2020

Mohammad Imdadul Haque, Ph.D. Associate Professor, Department of Management, College of Business Administration, Prince Sattam Bin Abdulaziz University, Saudi Arabia.

\title{
ASSESSING THE PROGRESS OF EXPORTS DIVERSIFICATION IN SAUDI ARABIA: GROWTH-SHARE MATRIX APPROACH
}

\begin{abstract}
High dependence on a particular category of exports results in fluctuations in income as the price of the export item fluctuates. In Saudi Arabia, a single category of mineral exports forms over $78 \%$ of the total exports, exposing the country to revenue volatility. The study aims to assess the magnitude of diversification of the export basket for the country. It uses data from 1984 to 2018 to study the importance of non-mineral exports in total exports. It applies Granger causality, variance decomposition, and impulse response function in the vector autoregressive framework. The study also uses the growth-share matrix to evaluate individual items of non-mineral exports. The results show a long-run relationship with a $1 \%$ increase in non-mineral exports, leading to a $0.30 \%$ increase in total exports. Non-mineral exports Granger-cause total exports. In the long run, non-mineral exports have a share of $64 \%$ of the forecast error variance in total exports. Moreover, a $1 \%$ shock in non-mineral exports creates a huge initial impact on total exports. Also, the growth rate of non-mineral products is higher than mineral products. The results indicate the importance of non-mineral exports for a predominantly oil-exporting country. Finally, the study attempts to classify its nonmineral export categories based on growth rates and market shares. Targeted emphasis on export category with a strong growth rate and low market share can be an effective strategy for further export diversification.
\end{abstract}

Keywords

JEL Classification

\section{INTRODUCTION}

Diversification of exports is a product mix in the existing exports of an economy, and it is a transformation of the exports from conventional to innovative in most of the emerging nations. The composition of exports and their diversification have an impact on the economic development of a nation. They lead to income stability from exports, particularly during the period of price volatility of exporting items. The core objective of export diversification is to mitigate political and economic risks. It further aims at broadening the geographical boundaries of exports. Export diversification results in better allocation of resources, better utilization of capacities, attainment of economies of scale, knowledge spillovers, improvement of total factor productivity and higher economic growth (Herzer \& Lehman, 2006; Aditya \& Acharya, 2013; Ali, 2017).

The Kingdom of Saudi Arabia is one of the largest producers of oil worldwide, and it relies mainly on oil as its source of income. In 2018, the oil sector gross domestic product (GDP) constituted over $43 \%$ of the total GDP. Besides, only one item, namely mineral products, has constituted over $78 \%$ of the total exports. Saudi Arabia transformed 
dramatically after 1973-1974, owing to a huge spurt in revenues from oil export. However, with the collapse of oil prices in 1982-1983, the country felt the need to generate revenues from the resources available in the country other than oil. Non-mineral exports, as a percentage of total exports, have increased from $3.29 \%$ in 1984 to $21.03 \%$ in 2018 (SAMA, 2019). The recent fall in crude oil prices in 2014 and the announcement of Vision 2030 in 2016 has renewed the emphasis on export diversification. Vision 2030 is a structural transformation plan aimed at moving the country away from oil, emphasizing small and medium industries, the private sector, and export diversification.

This study identifies the assessment of Saudi Arabia's export diversification as its research problem. Export diversification is essential for an oil-exporting economy, particularly for two reasons. First, though there is a faint chance of deterioration of terms of trade because of a fall in prices, oil is a highly demanded commodity. However, the fluctuation of oil prices is a serious issue. This is referred to as the 'portfolio effect' where export diversification helps in attaining stability in export income, as it does away with the dependence on the volatility of the price. Two recent falls in oil prices in 2008 and 2014 have exposed the country to the vagaries of oil price fluctuations. Second, oil revenues may lead a country to a 'resource curse', wherein other manufacturing sectors become unproductive because of the 'rent-seeking' nature of the country. This calls for diversifying the economy. The extent of diversification of the economy can be judged through the diversification of the export basket of the country.

\section{LITERATURE REVIEW}

The discussion between export diversification and economic development dates back to the seminal works of Prebisch (1950) and Singer (1950). They hypothesized that the terms of trade for primary products deteriorate vis-a-vis manufactured products. A diversification in exports saves an economy predominantly exporting primary goods from the deterioration of terms of trade. Later, the concept of 'Dutch Disease' emerged wherein growth in a sector led by factors related to natural resources leads to a reduction in other sectors like manufacturing, making the economy uncompetitive (Corden \& Neary, 1982). This abundance of natural resources leading to lower economic growth is also referred to as the 'natural resource curse' (Auty, 1993). Later, Sachs and Warner (1995) found a negative correlation between resource abundance measured by the percentage of primary products in exports and growth, as it crowds out manufacturing sector activity.

Countries that export mineral products like Saudi Arabia tend to depend on its leading sector heavily have certain characteristics, and specific challenges as production linkages are limited, and natural rent is high (Gelb, 2010). This can be referred to as the metaphor of 'sowing the oil' generally used in the context of Venezuela. Hence, there is a fear that countries are 'locked-in' to the overde- pendence of exporting its dominant product, and finally, the 'Dutch Disease' syndrome takes in where the countries' growth suffers because of its abundant resources (Hendrix, 2017). Nevertheless, the oil sector has its own distinct set of forward and backward linkages (Al-Moneef, 2006). These countries need first to develop its upstream activities involving resource extraction systems and the production of equipment required for extraction (Ramos, 1998). Here, the country achieves diversification first by the import substitution strategies wherein the machinery required for extraction is produced and then, at a later stage by exporting the machinery items (Altowaim, 2019).

Diversification invalidates the natural recourse curse generally associated with oil-abundant countries (Oyinlola, Adeniyi, \& Raheem, 2015). Also, export diversification in resource-rich countries needs different strategies than resource-poor countries (Arawomo, 2015). In terms of export baskets, resource-rich countries have lower diversification. The countries whose export baskets have more technologically sophisticated products grow faster than countries with less sophisticated items in their export baskets. Nevertheless, oil revenues are solely responsible for the growth and development of Saudi Arabia (Haque \& Khan, 2018). Hence, the case of Saudi Arabia is perplexing as its export basket is not sophisticated, but its per capita income is high (Esanov, 2012). Ocampo (2016) 
refers to this as a 'resource-rich high-income trap.' It refers to the failure of promoting sectors producing technologically sophisticated items that are crucial to increase productivity and growth.

The researcher searched for studies on export diversification in the context of Saudi Arabia. Few studies are available, and they are quoted here. Nicet-Chenaf and Rougier (2008) found that for the period 1995-2004, export diversification had a positive effect on economic growth in the Middle East and North African (MENA) region. Dogruel and Tekce (2011) reported no increase in the portion of non-oil exports in 1991-2009. Alaya (2012) studied MENA countries, including Saudi Arabia, for the period 1984-2009 and found that greater resource endowments led to export concentration. Al Bakr (2015) acknowledged diversification of product based diversification as an essential aspect of economic growth for the period 2010-2014. Alsharif, Bhattacharya, and Intartaglia (2017) reported an increase in non-oil exports and opined that there is further scope of export diversification from 1962 to 2012. Aljebrin (2017) found a cointegrating relationship between non-oil exports and non-oil economic growth for the period 1988-2014.

Altowaim (2019) developed product space in line with Hidalgo, Klinger, Barabási, and Hausmann (2007) for 2016 exports of Saudi Arabia and called for further diversification of the upstream and downstream sectors of the oil industry, particularly emphasized chemical and pharmaceutical as they are price inelastic. Hidalgo, Klinger, Barabási, and Hausmann (2007) conceptualized 'Product space' theory where diversification is movement from the core (dominated by primitive items) to the periphery (dominated by sophisticated items). Abdelhadi, Bashayreh, and Alomari (2019), in their study on MENA countries for the period 1990-2016, found an insignificant positive impact of export instability on growth.

Except for Dogruel and Tekce (2011), all other studies on Saudi Arabia reports an increase in non-oil exports in their respective period of study. However, these studies are covering the data until the year 2016. There is a literature gap in terms of a study covering the latest period for which the data are available. Hence, it becomes significant for the current research to examine the extent of the country's diversification of exports. There is a dearth of research that studies export diversification in Saudi Arabia until 2018 (the current year for which the data is available). Particularly the period after 2014 is important as oil prices fell considerably, and the country announced Vision 2030, a structural transformation program.

\section{AIMS}

This study aims to assess the extent of export diversification in Saudi Arabia through the growth of non-mineral exports. Besides, the study also aims to contribute to the existing literature by identifying sectors with higher export potential.

\section{DATA AND METHODS}

The study uses the data for total exports (TE), mineral exports (ME), and non-mineral exports (NME). The data is taken from the Saudi Arabian Monetary Agency. It categorizes its exports into "Mineral Products, Foodstuffs, Chemical Products, Plastic Products, Base Metals and Articles of Base Metals, Electrical Machines, Equipment \& Tools, Other Exports, and Re-exports." The data for non-mineral exports is taken by adding all the types of exports except for mineral exports. The data are annual, and the period of study is from 1984 to 2018.

Mineral exports constitute a major portion of the total exports. In 2008, there was a drop in mineral exports; hence, total exports also dropped. The next fall in mineral exports and total exports happened in 2014. The rise and fall in total exports are solely due to the movements in mineral products (Figure 1). Total exports fall and rise when mineral exports fall and rise. On the contrary, non-mineral exports are gradually increasing.

The data are tested for the presence of unit root through Augmented Dickey-Fuller tests. Here the hypotheses are Null hypothesis: the data contains a unit root; Alternate hypothesis: the data has no unit root. Acceptance of the Null hypothesis indicates that the data are not stationary. The same test is repeated, taking the first difference of the data. 


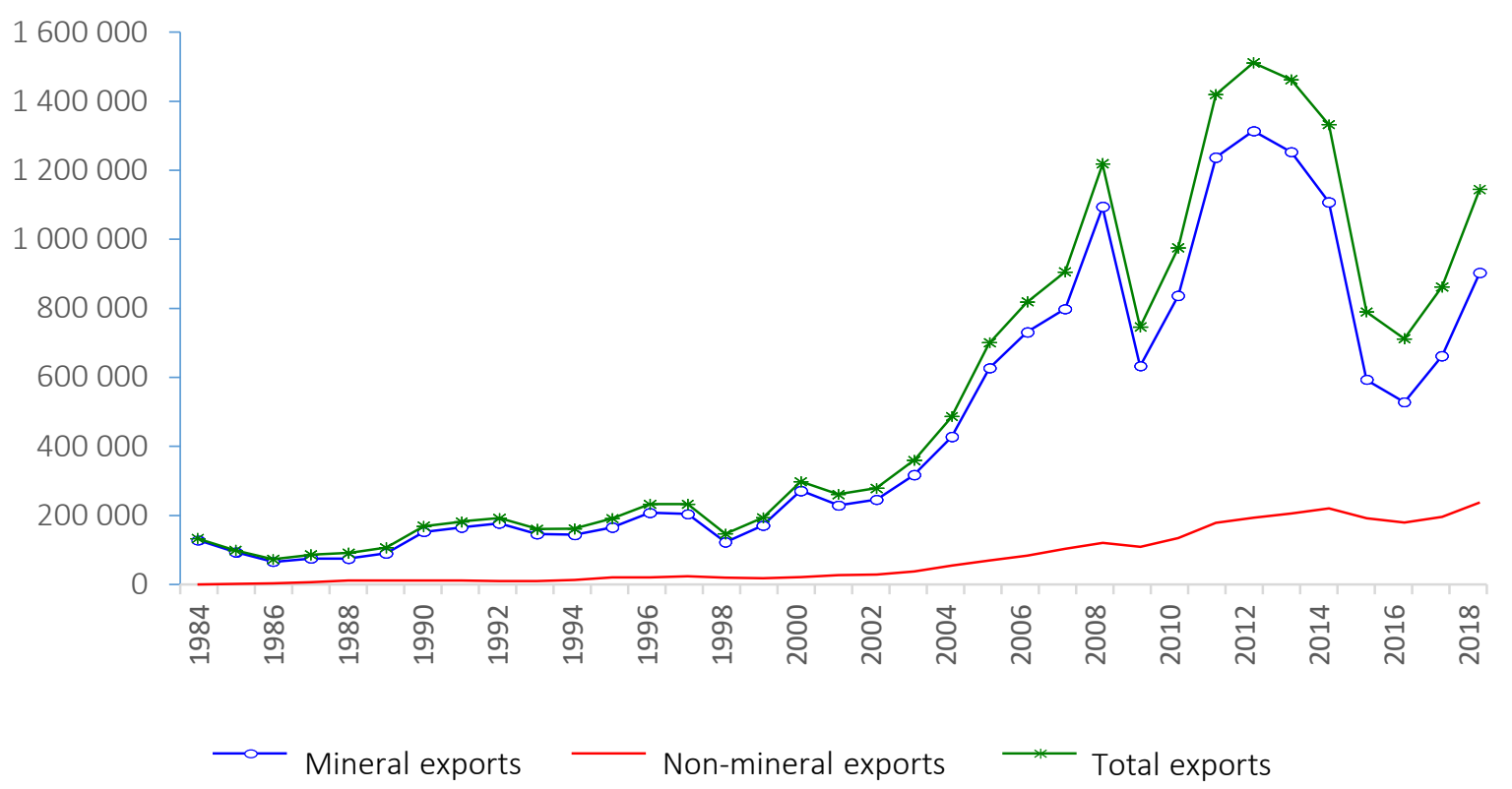

Figure 1. Graphical presentation of the data (in million Riyals)

Granger (1969) devised a causality test to confirm whether the inclusion of one variable's previous values advances the prediction of another variable's current values. As in this study's case, if TE's prediction is enhanced by incorporating prior values of $N M E$ as compared to using only the past values of TE, then NME is said to Granger-cause TE. Similarly, if the prior values of $T E$ enhance the prediction of $N M E$ as compared to when using only the prior values of $N M E$, then TE is said to Grangercause NME. This study proposes to estimate the given equations (1) and (2) in the Vector Autoregressive (VAR) framework. Here all the variables are taken to be endogenous, and a particular autoregressive lag length $p$ is assumed. To ascertain a relationship between non-mineral exports and total exports, the following two equations that are estimated:

$$
\begin{aligned}
& N M E=\alpha_{1}+\sum_{j=1}^{k} \beta_{j} N M E_{t-j}+ \\
& +\sum_{j=1}^{k} \gamma_{j} T E_{t-j}+\varepsilon_{1 t} \\
& T E=\alpha_{2}+\sum_{j=1}^{k} \delta_{j} T E_{t-j}+ \\
& +\sum_{j=1}^{k} \rho_{j} N M E_{t-j}+\varepsilon_{2 t} .
\end{aligned}
$$

The Granger causality determines the amount in which the present level of one variable depends on its prior levels. It now asserts that upon that, the results can be further advanced by including prior values of the other variables. Impulse response function (IRF) and variance decomposition follow this. IRF sketches the outcome of a one standard deviation shock to innovation on the endogenous variable's present and upcoming values. Variance decomposition shows the strength of the independent variables explaining the variability in the dependent variables over time. It shows the forecast error of the variable for each forecast horizon.

Finally, three tests are conducted to assess the fitness of the residuals of the model. The first is a test for serial correlation. Here the hypotheses are Null hypothesis: there is no serial correlation; Alternate hypothesis: there is a serial correlation. Second is the test for the normality of residuals. Here the hypotheses are Null hypothesis: the residuals are normally distributed. Alternate hypothesis: the residuals are not normally distributed. The third is the test for heteroscedasticity. Here the hypotheses are Null hypothesis: the residuals are homoscedastic; Alternate hypothesis: the residuals are heteroscedastic. In all the cases, the decision is taken based on the $p$-values. A $p$-value of more than 0.05 indicates acceptance of the Null hypothesis at 5\% level of significance. 


\section{RESULTS}

Table 1 shows that the data of both non-mineral exports and total exports are non-stationary at the level and stationary at first difference.

Next, the lag order for the variables is ascertained in VAR framework. All the criteria for determining lag order (except LogL) indicate a lag of 1 (Table 2). Hence, lag1 is identified for further analysis.

The VAR results are presented in Table 3. Both models have a high and significant R-squared value. The study uses Ordinary Least Square estimates to get the significance scores. The two estimated equations are:

$$
\begin{aligned}
& N M E=C(1) \cdot N M E(-1)+C(2) \cdot T E(-1)+C(3) \\
& T E=C(4) \cdot N M E(-1)+C(5) \cdot T E(-1)+C(6)
\end{aligned}
$$

The results indicate that in the equation with non-mineral exports as the dependent variable, the slope coefficient of total exports is not significant. This indicates that total exports do not significantly influence non-mineral exports. In the next equation, wherein total exports is the dependent variable, that is $N M E(-1)$ and $T E(-1)$ are significant (Table 3 ). The past realization of total exports is associated with a 0.61 percent increase in total exports (Table 4). In contrast, a one percent increase in non-mineral exports leads to a 0.30 percent increase in total exports.

Table 1. Augmented Dickey-Fuller tests

\begin{tabular}{|c|c|c|c|c|}
\hline \multirow{2}{*}{ ADF } & \multicolumn{2}{|c|}{ NME at level } & \multicolumn{2}{|c|}{ NME at first difference } \\
\hline & t-statistic & Prob. & t-statistic & Prob. \\
\hline Constant & -1.45848 & 0.5421 & -3.884701 & 0.0055 \\
\hline Constant, linear trend & -2.87157 & 0.1841 & -3.829798 & 0.0274 \\
\hline None & 4.217830 & 1.0000 & -2.946176 & 0.0045 \\
\hline \multirow{2}{*}{ ADF } & \multicolumn{2}{|c|}{ TE at level } & \multicolumn{2}{|c|}{ TE at first difference } \\
\hline & t-statistic & Prob. & t-statistic & Prob. \\
\hline Constant & -0.60744 & 0.856 & -4.994327 & 0.0003 \\
\hline Constant, linear trend & -2.51025 & 0.3215 & -4.915763 & 0.0020 \\
\hline None & 1.385098 & 0.9555 & -4.705644 & 0.0000 \\
\hline
\end{tabular}

Source: Author's calculation.

\begin{tabular}{|c|c|c|c|c|c|c|}
\hline Lag & LogL & LR & FPE & AIC & SC & $\mathrm{HQ}$ \\
\hline 0 & -44.016 & NA & 0.066741 & 2.968768 & 3.061283 & 2.998925 \\
\hline 1 & 24.45434 & $123.6882^{*}$ & $0.001044 *$ & -1.1906 & $-0.913057^{*}$ & $-1.100130 *$ \\
\hline 2 & 26.74369 & 3.840204 & 0.001171 & -1.08024 & -0.61766 & -0.92945 \\
\hline 3 & 31.15833 & 6.835565 & 0.001151 & -1.10699 & -0.45938 & -0.89589 \\
\hline 4 & 36.95902 & 8.233240 & 0.001044 & $-1.223163^{*}$ & -0.39053 & -0.95174 \\
\hline
\end{tabular}

Table 2. VAR Lag order selection

Note: * Lag length selected based on criteria.

\begin{tabular}{|c|c|c|}
\hline Variables & NME & TE \\
\hline \multirow{3}{*}{$N M E(-1)$} & 0.899302 & 0.304922 \\
\hline & $(0.07429)$ & $(0.11721)$ \\
\hline & [12.1059] & [2.60143] \\
\hline \multirow{3}{*}{$T E(-1)$} & 0.088170 & 0.612073 \\
\hline & (0.09176) & $(0.14479)$ \\
\hline & {$[0.96086]$} & [4.22743] \\
\hline \multirow{3}{*}{ C } & 0.060738 & 1.770747 \\
\hline & $(0.48108)$ & $(0.75908)$ \\
\hline & {$[0.12625]$} & [2.33275] \\
\hline R-squared & 0.983644 & 0.941751 \\
\hline F-statistic & 932.1811 & 250.5997 \\
\hline
\end{tabular}

Table 3. Vector autoregression estimates 
Table 4. Least squares estimates

Source: Author's calculation.

\begin{tabular}{l|c|c|c|c}
\hline Variables & Coefficient & Std. error & t-statistic & Prob. \\
\hline$C(1)$ & 0.899302 & 0.074286 & 12.10586 & 0 \\
\hline$C(2)$ & 0.08817 & 0.091761 & 0.96086 & 0.3404 \\
\hdashline$C(3)$ & 0.060738 & 0.481084 & 0.126252 & 0.8999 \\
\hdashline$C(4)$ & 0.304922 & 0.117213 & 2.601429 & 0.0116 \\
\hdashline$C(5)$ & 0.612073 & 0.144786 & 4.227432 & 0.0001 \\
\hdashline$C(6)$ & 1.770747 & 0.75908 & 2.332753 & 0.0229 \\
\hline
\end{tabular}

Once the long-run relationship is ascertained, Granger causality test is conducted to test for causality. The results indicate that total exports do not Granger-cause non-mineral exports, while non-mineral exports Granger-cause total exports (Table 5).

Table 5. VAR Granger causality/block exogeneity Wald tests

Source: Author's calculation.

\begin{tabular}{|c|c|c|c|}
\hline \multicolumn{4}{|c|}{ Dependent variable: $N M E$} \\
\hline Excluded & Chi-sq & df & Prob. \\
\hline TE & 0.923251 & 1 & 0.3366 \\
\hline All & 0.923251 & 1 & 0.3366 \\
\hline \multicolumn{4}{|c|}{ Dependent variable: $T E$} \\
\hline Excluded & Chi-sq & $d f$ & Prob. \\
\hline NME & 6.767432 & 1 & 0.0093 \\
\hline All & 6.767432 & 1 & 0.0093 \\
\hline
\end{tabular}

Variance decomposition shows the explanatory variables' strength in explaining the variability in the dependent variables over time. It shows the forecast error of the variable for each forecast horizon. In the short run (at time 1), $28 \%$ of the forecast error variance is explained by $N M E$, while $71.34 \%$ is the forecast error variance explained by total exports itself. At time 2, 36.26\% of the forecast error variance is explained by $N M E$, while $63.73 \%$ is the forecast error variance explained by total exports itself. In the long run (period 10), $64 \%$ of the forecast error variance is explained by $N M E$, while $35.97 \%$ is the forecast error variance explained by total exports itself.

The Impulse Response Function (IRF) shows that a one percent shock in NME initially created a huge impact on $T E$, but later it remained constant (Figure 2). IRF shows that a one standard deviation shock in NME has a positive impact on total exports (from period 1 to period 5). The impact then becomes stable and remains positive in the long run also. Besides, a one standard deviation shock in total exports leads to total exports to decline from period 1 to period 5 , it slowly increases until period 7, and finally, it remains stable. Nevertheless, it remains positive for the entire period.

Finally, to check the fitness of the model, the residual test is conducted. Table 7 depicts the results of the test for serial correlation. As the $p$-values are more than 0.05 , the Null hypothesis of no serial correlation is accepted.

Table 8 depicts the results of the test for normality. As the $p$-value is more than 0.05 , the Null hy-

Table 6. Variance decomposition

Source: Author's calculation.

\begin{tabular}{|c|c|c|c|c|c|c|}
\hline \multirow[b]{2}{*}{ Period } & \multicolumn{3}{|c|}{ NME } & \multicolumn{3}{|c|}{ TE } \\
\hline & S.E. & NME & TE & S.E. & NME & TE \\
\hline 1 & 0.149264 & 100.0000 & 0.000000 & 0.235517 & 28.65784 & 71.34216 \\
\hline 2 & 0.209079 & 99.29626 & 0.703736 & 0.292138 & 36.26155 & 63.73845 \\
\hline 3 & 0.253865 & 98.43231 & 1.567692 & 0.325551 & 42.65423 & 57.34577 \\
\hline 4 & 0.290503 & 97.67275 & 2.327253 & 0.350345 & 47.83955 & 52.16045 \\
\hline 5 & 0.321670 & 97.06245 & 2.937552 & 0.370825 & 52.01535 & 47.98465 \\
\hline 6 & 0.348791 & 96.58468 & 3.415322 & 0.388623 & 55.39833 & 44.60167 \\
\hline 7 & 0.372754 & 96.21131 & 3.788685 & 0.404498 & 58.16905 & 41.83095 \\
\hline 8 & 0.394163 & 95.91702 & 4.082977 & 0.418862 & 60.46599 & 39.53401 \\
\hline 9 & 0.413455 & 95.68205 & 4.317954 & 0.431976 & 62.39282 & 37.60718 \\
\hline 10 & 0.430956 & 95.49173 & 4.508270 & 0.444019 & 64.02710 & 35.97290 \\
\hline
\end{tabular}


Source: Author's calculation using EViews 10 output.

Response to Cholesky One S.D. (d.f. adjusted) Innovations \pm 2 S.E.

Response of NME to NME

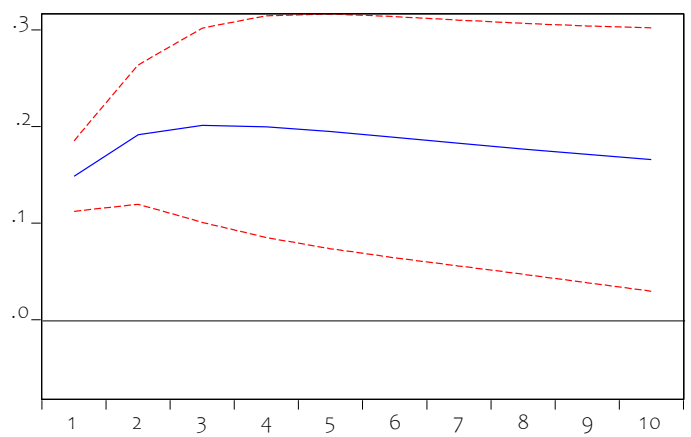

Response of TE to NME

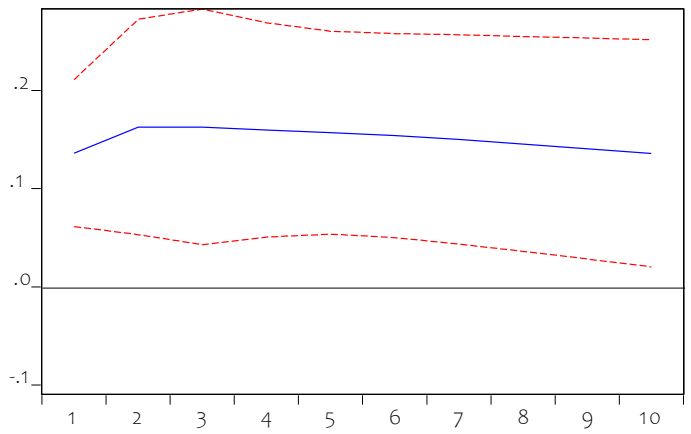

Response of NME to TE

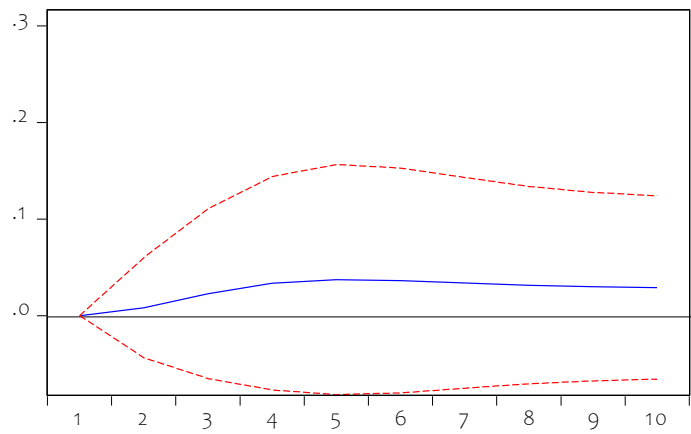

Response of TE to TE

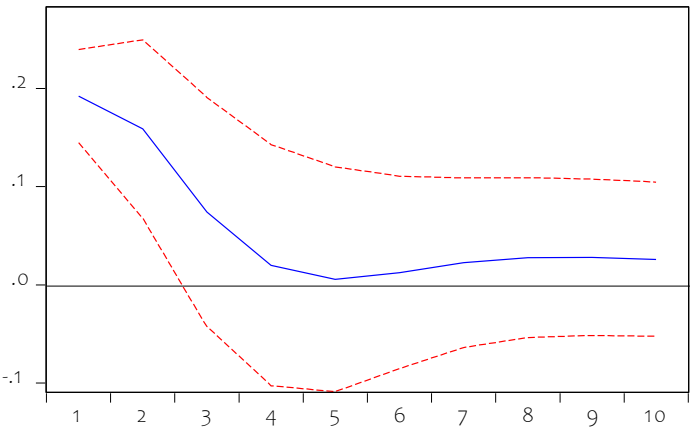

Figure 2. Impulse response function

pothesis of the normally distributed residuals is accepted.

Table 9 depicts the results of the test for heteroscedasticity. As the $p$-value is more than 0.05 , the Null hypothesis of homoscedastic residuals is accepted.

Table 7. VAR residual serial correlation LM tests
As the above analysis indicates that overall non-mineral exports significantly impact the total export, hence a comprehensive analysis of non-mineral items is proposed, as is evident in Table 1, the CAGR of non-mineral exports $(11.9 \%)$ is higher than mineral products $(8.6 \%)$. This indicates that the growth rate of non-miner-

Source: Author's calculation.

\begin{tabular}{|c|c|c|}
\hline Lags & LM stat & Prob. \\
\hline 1 & 6.734177 & 0.1506 \\
\hline 2 & 3.274854 & 0.5129 \\
\hline 3 & 0.903284 & 0.9241 \\
\hline 4 & 5.176613 & 0.2697 \\
\hline 5 & 6.381655 & 0.1724 \\
\hline 6 & 0.243720 & 0.9932 \\
\hline 7 & 3.283150 & 0.5116 \\
\hline 8 & 0.355311 & 0.9860 \\
\hline 9 & 4.526419 & 0.3394 \\
\hline 10 & 4.284241 & 0.3689 \\
\hline 11 & 4.946450 & 0.2928 \\
\hline 12 & 6.784083 & 0.1477 \\
\hline
\end{tabular}


Table 8. VAR residual normality tests

Source: Author's calculation.

\begin{tabular}{c|c|c|c}
\hline Component & Jarque-Bera & df & Prob. \\
\hline 1 & 3.084425 & 2 & 0.2139 \\
\hline 2 & 2.976404 & 2 & 0.2258 \\
\hline Joint & 6.060829 & 4 & 0.1947 \\
\hline
\end{tabular}

Table 9. VAR residual heteroscedasticity tests

Source: Author's calculation.

\begin{tabular}{c|c|c|c|c|c}
\hline \multicolumn{2}{c|}{ Joint test: includes cross-terms } & \multicolumn{3}{c}{ Joint test: no cross-terms } \\
\hline Chi-sq & df & Prob. & Chi-sq & df & Prob. \\
\hline 19.52048 & 15 & 0.1911 & 16.72314 & 12 & 0.1603 \\
\hline
\end{tabular}

al products is higher than that of mineral products. Plastic products (15.9\%), Other Exports (15.8\%), Base Metals and Articles of Base Metals (12.2\%), Foodstuffs (11.8\%), Re-exports (11.2\%), and lastly Chemical Products (10.9\%), of Electrical Machines, Equipment \& Tools (17.5\%), follow the highest growth. The last three items, namely Foodstuffs, Re-exports, and Chemical Products, have a growth rate lower than the average growth of Non-mineral products (11.9\%). However, interestingly, Chemical Products have the largest market share (6.74\%) after Chemical Products (7.09\%) in the category of Non-mineral products. Besides, the items among non-mineral products that had the highest growth rate, that is, Electrical Machines, Equipment \& Tools, had a market share of $0.63 \%$ only.

Next, a growth-share matrix proposed by Boston Consulting Group to strategic planning is applied. It divides classifies businesses into four different groups based on the attractiveness of the industry and its competitive position. This study characterizes industry attractiveness with compound annual growth rates and competitiveness with market share. The four different classifications are 'Dog, Question mark, Cash cow, and Star.' The first category, Dog', has both low growth rates and low market share. The second category, 'Question mark,' has high growth rates but low market share. The third category, 'Cash cow,' has low growth rates but a high market share. Besides, the fourth category, 'Star,' has both high growth rates and high market share.

The compound annual growth rates and market shares of non-mineral products are provided in Table 10 . The average growth rate of $11.9 \%$ is the benchmark to divide export categories as high or low growth rates. Also, the average market share of non-mineral products in 2018 of 3\% is taken as the benchmark to decide high/low market share. Foodstuffs, Electrical machines, Base metals, and Other exports are categorized as 'Question mark' as they have high growth but low market share. Chemical products are categorized as in the 'Cash cow' category as they have low growth rates and a high market share. Plastic products are catego-

Table 10. Descriptive statistics of the data

Source: Author's calculation.

\begin{tabular}{|c|c|c|c|c|c|}
\hline Item & Range & Mean & Std. deviation & CAGR & $\%$ of total exports in 2018 \\
\hline Foodstuffs & 13,400 & $5,243.30$ & $5,086.31$ & 11.8 & 1.17 \\
\hline Chemical Products & 72,900 & 24,846 & $23,461.95$ & 10.9 & 6.74 \\
\hline Plastic Products & 78,200 & 21,114 & $24,829.11$ & 15.9 & 7.09 \\
\hline Base Metals and Articles of Base Metals & 19,400 & $5,315.10$ & $5,212.41$ & 12.2 & 1.77 \\
\hline Electrical Machines, Equipment \& Tools & 6,382 & $1,997.30$ & $1,801.19$ & 17.5 & 0.36 \\
\hline Other exports & 11,700 & $5,061.90$ & $4,434.15$ & 15.8 & 1.02 \\
\hline Re-exports & 31,000 & 11,608 & $11,918.71$ & 11.2 & 2.87 \\
\hline Non-mineral products (total) & 228,000 & 75,186 & $75,299.26$ & 11.9 & 21.03 \\
\hline Mineral Products & $1,200,000$ & 443,280 & 378,959 & 8.6 & 78.97 \\
\hline Total exports & $1,380,000$ & 518,460 & 447,052 & 9 & - \\
\hline
\end{tabular}




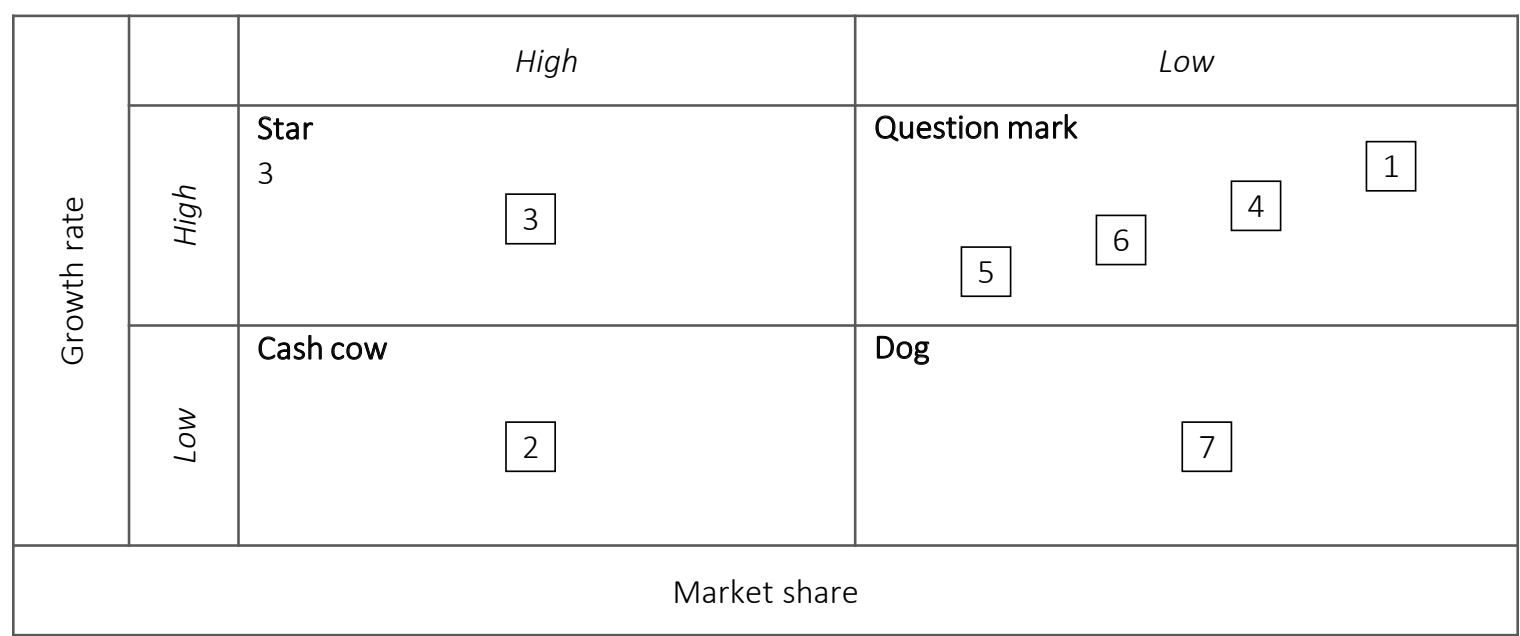

Note: 1 - Foodstuffs, 2 - Chemical Products, 3 - Plastic Products, 4 - Base Metals and Articles of Base Metals, 5 - Electrical Machines, Equipment \& Tools, 6 - Other exports, 7 - Re-exports.

Figure 3. Growth-share matrix

rized to be in 'Star' category as it has both a high growth rate and high market share. Re-exports is categorized as a 'Dog' category as it has a relatively low growth rate and market share. Giving more targeted emphasis on these items where there is a strong growth rate accompanied by low market share could be an effective strategy to expedite the process of export diversification.

\section{DISCUSSION}

The exports of Saudi Arabia are concentrated in one type of commodity: mineral products, and since the country is journeying towards an economic transition, there is a dire need to diversify to other products. This relationship is important, as historically there have been huge fluctuations in mineral exports. This fluctuation has hugely affected the total exports. Now, as an alternative, the non-mineral exports are also significantly affecting total exports. This will help in moving away from the volatile effects of mineral products. Further strengthening of this relationship would be instrumental in successfully diversifying away from mineral exports. This will ascertain a stable and sustainable income from exports.

The results imply that non-mineral exports are significant in affecting total exports. Estimates in the VAR framework indicate that a $1 \%$ increase in non-mineral exports leads to a $0.30 \%$ increase in total exports. Granger causality results show that non-mineral exports do cause total exports. Variance decomposition results indicate that the non-mineral exports would increasingly explain the amount of variation in total exports in the long run. IRF shows that shocks to non-mineral exports will positively impact total exports, both in the short run and the long run. Besides, as total exports do not significantly affect non-mineral exports, it implies that the non-mineral exports are independent of mineral exports. Therefore, any issues in mineral exports would not adversely affect the non-mineral exports.

The results of this study contradict the findings of Dogruel and Tekce (2011) and support the findings of Al Bakr (2015), Alsharif, Bhattacharya, and Intartaglia (2017) and Aljebrin (2017) regarding the growth of the non-oil sector. Moreover, according to the growth-share matrix, the country should emphasize where the growth rate is high, and market share is less as there is a scope to increase its market share. Electrical Machines, Equipment \& Tools had the highest growth rate, but it also constitutes the smallest share in exports. Hence, this study recommends targeting this category of exports to increase its market share in total exports. This is also in line with the Product Space theory of Hidalgo, Klinger, Barabási, and Hausmann (2007), which calls for shifting to the production and export of technologically sophisticated items. 


\section{CONCLUSION}

This study reviews the export basket of Saudi Arabia. Total exports have been fluctuating, particularly due to fluctuations in mineral products, while non-mineral exports have been slowly and steadily rising. Estimates in the vector autoregressive framework indicate that a one percent increase in non-mineral exports is associated with a $0.30 \%$ increase in total exports. Non-mineral exports Granger-cause total exports, implying that past values of non-mineral exports are significant in explaining future values of total exports. In the long run, $64 \%$ of the forecast error variance in total exports is explained by non-mineral exports. Impulse response function indicates that the impact on total exports of shock in non-mineral exports is positive in the long run. Residual diagnostics establish that the model is fit and free from errors.

The seven items of non-mineral products constitute only $21 \%$ of the total exports of Saudi Arabia, while the remaining $79 \%$ belong to a single category of mineral exports. However, the compound annual growth rate for non-mineral products is $11.9 \%$, which is higher than both for mineral products $(8.6 \%)$ and total exports (9\%). The study further categorizes its exports using the compound annual growth rate and market share to construct a growth-share matrix for the non-mineral exports. The study recommends an emphasis on export category with high growth rates and low current market share. The novelty of this study is that it identifies the category of electrical goods to accelerate the diversification of the export basket. Further scope of the study would be studying the individual items of non-mineral exports in detail.

\section{AUTHOR CONTRIBUTIONS}

Conceptualization: Mohammad Imdadul Haque.

Data curation: Mohammad Imdadul Haque.

Formal analysis: Mohammad Imdadul Haque.

Investigation: Mohammad Imdadul Haque.

Methodology: Mohammad Imdadul Haque.

Resources: Mohammad Imdadul Haque.

Software: Mohammad Imdadul Haque.

Supervision: Mohammad Imdadul Haque.

Validation: Mohammad Imdadul Haque.

Visualization: Mohammad Imdadul Haque.

Writing - original draft: Mohammad Imdadul Haque.

Writing - review \& editing: Mohammad Imdadul Haque.

\section{REFERENCES}

1. Abdelhadi, S., Bashayreh, A. G., \& Alomari, M. W. (2019). The impact of export instability on economic growth: sample of MENA countries. International Journal of Economics and Business Research, 18(4), 429-435. https://doi. org/10.1504/IJEBR.2019.10024409

2. Aditya, A., \& Acharya, R. (2013). Export Diversification, Composition and Economic Growth: Evidence from Cross Country Analysis. The Journal of
International Trade and Economic Development, 22(7), 959-992. https://doi.org/10.1080/09638199. 2011.619009

3. Al Bakr, A. (2015). Challenges to Production Base Diversification in Saudi Arabia (SAMA Working Paper No. WP/15/8). Economic Research Department, Saudi Arabian Monetary Agency. Retrieved from http://www.sama. gov.sa/en-US/EconomicResearch/ WorkingPapers/Challenges\%20 to $\% 20$ Production\%20Base $\% 20 \mathrm{Di}$ versification $\% 20 \mathrm{in} \% 20$ Saudi\%20 Arabia.pdf

4. Alaya, M. (2014). The Determinants of MENA Export Diversification: An Empirical Analysis (Working paper No. 709). The Economic Research Forum, Egypt. Retrieved from https://erf. org.eg/app/uploads/2014/08/709. pdf

5. Ali, M. (2017). Determinants of Related and Unrelated Export 
Diversification. Economies, 5(4), 1-21. https://doi.org/10.3390/ economies5040050

6. Aljebrin, M. A. (2017). Impact of Non-oil Export on Non-oil Economic Growth in Saudi Arabia. International Journal of Economics and Financial Issues, 7(3), 389397. Retrieved from https://www. econjournals.com/index.php/ijefi/ article/view/4630

7. Al-Moneef, M. (2006). The Contribution of the Oil Sector to Arab Economic Development, Paper presented at the High-level Roundtable Partnership for Arab Development. Paper presented at High-level Roundtable Partnership for Arab Development: A Window of Opportunity. Retrieved from http://www.adelinotorres.info/mediooriente/arabes_petroleo_e_desenvolvimento_dos_paises_arabes. pdf

8. Alsharif, N., Bhattacharya, S., \& Intartaglia, M. (2017). Economic Diversification in Resource Rich Countries: History, State of Knowledge and Research Agenda. Resources Policy, 52, 154-164. https://doi.org/10.1016/j.resourpol.2017.02.007

9. Altowaim, S. (2019). Promoting Industrial and Export Diversification in ResourceDependent Countries the Case of Saudi Arabia (SAMA Working Paper No. WP/19/03). Saudi Arabian Monetary Agency, Riyadh. Retrieved from http://www.sama. gov.sa/en-US/EconomicResearch/ WorkingPapers/Promoting\%20Industrial\%20and\%20Export\%20Diversification $\% 20 \mathrm{in} \% 20$ ResourceDependent\%20Countries.pdf

10. Arawomo, D. F. (2015). A comparative analysis of export diversification in resource rich and non-resource rich countries. International Journal of Sustainable Economy, 7(4), 327-341. https://doi.org/10.1504/ IJSE.2015.072199

11. Auty, R. M. (1993). Sustaining Development in Mineral Economies (The Resource Curse Thesis). London: Routledge.

12. Corden, W. M., \& Neary, J. P. (1982). Booming Sector and De- industrialisation in a Small Open Economy. The Economic Journal, 92(368), 825-848. https://doi. org/10.2307/2232670

13. Dogruel, A. S., \& Tekce, M. (2011) Trade Liberalization and Export Diversification in Selected MENA Countries. Topics in Middle Eastern and African Economies, 13, 1-24. Retrieved from http://meea. sites.luc.edu/volume13/PDFS/ Dogruel_Tekce_R2.pdf

14. Esanov, A. (2012). Economic Diversification: Dynamic, Determinants and Policy Implication. Revenue Watch Institute. Retrieved from https:// resourcegovernance.org/sites/ default/files/RWI_Economic_Diversification.pdf

15. Gelb, A. (2010). Economic Diversification in Resources Rich Countries. Washington, D.C.: Centre for Global Development. Retrieved from https://www. imf.org/external/np/seminars/ eng/2010/afrfin/pdf/Gelb2.pdf

16. Haque, M. I., \& Khan, M. R. (2019). Role of oil production and government expenditure in improving Human Development Index: Evidence from Saudi Arabia. International Journal of Energy Economics and Policy, 9(2), 251-256. https://doi.org/10.32479/ ijeep.7404

17. Hendrix, C. (2017). Kicking a crude habit: diversifying away from oil and gas in the twenty-first century. International Review of Applied Economics, 33(2), 188-208. https://doi.org/10.1080/02692171. 2017.1389862

18. Herzer, D., \& Lehmann, N. (2006). What does Export Diversification do for a Growth? An Econometric Analysis. Applied Economic, 38(15), 1825-1838. https://doi. org/10.1080/00036840500426983

19. Hidalgo, C. A., Klinger, B., Barabási, A.-L., \& Hausmann, R. (2007). The Product Space Conditions the Development of Nations. Science, 317(5837), 482-487. https://doi. org/10.1126/science.1144581

20. Nicet-Chenaf, D., \& Rougier, E. (2008). FDI, Diversification and Growth: an Empirical Assessment for MENA Countries (IMF staff papers). Retrieved from https:// pdfs.semanticscholar.org/6f28 /8c636aa0018aa799cc474a88f0 cebeaefdb6.pdf? ga $=2.15754$ 3935.494716779.15973884622100778558.1584432533

21. Ocampo, J. A. (2016). Foreword In R. Cherif, F. Hasanov, and Min Zhu (Eds.), Breaking the Oil Spell: The Gulf Falcons' Path to Diversification. Washington: International Monetary Fund. Retrieved from https://www. elibrary.imf.org/page/breakingoil-spell-excerpt

22. Oyinlola, M. A., Adeniyi, O. A., \& Raheem, I. D. (2015). Natural resource abundance, institutions and economic growth in Africa. African Journal of Economic and Sustainable Development, 4(1), 34-48. Retrieved from http:// www.inderscience.com/offer. php?id $=68513$

23. Prebisch, R. (1950). The Economic Development of Latin America and its Principal Problems. Economic Bulletin for Latin America, 7(1), 11-22. Retrieved from https://repositorio.cepal.org/ bitstream/handle/11362/10079/ S6200129.pdf? sequence $=1$

24. Ramos, J. (1998). A development strategy founded on natural resource-based production clusters. CEPAL Review, 66, 105-127. Retrieved from https:// repositorio.cepal.org/handle/11362/10668

25. Sachs, J. D., \& Warner, A. M. (1995). Natural resource abundance and economic growth (NBER Working Paper No. 5398). National Bureau of Economic Research. Retrieved from https:// www.nber.org/papers/w5398

26. SAMA. (2019). Annual Statistics 2019. Saudi Arabian Monetary Agency. Riyadh. Retrieved from http://www.sama.gov.sa/en-US/ EconomicReports/Pages/YearlyStatistics.aspx

27. Singer, H. (1950). The Distribution of Gains between Investing and Borrowing Countries. American Economic Review, 40(2), 473-485. https:// www.jstor.org/stable/1818065 